\title{
DÜBLIN
}

Technological University Dublin

ARROW@TU Dublin

\section{Antitumour and antimalarial activity of artemisinin-acridine hybrids}

\author{
Michael Jones \\ University of Liverpool \\ Amy Mercer \\ University of Liverpool \\ Paul Stocks \\ Liverpool School of Tropical Medicine
}

See next page for additional authors

Follow this and additional works at: https://arrow.tudublin.ie/scschcpsart

Part of the Heterocyclic Compounds Commons, Parasitic Diseases Commons, and the Pharmaceutics and Drug Design Commons

\section{Recommended Citation}

Jones, Michael, Amy E. Mercer, Paul A. Stocks, Louise J.I. La Pensée, Rick Cosstick, B. Kevin Park, Miriam E. Kennedy, et al. "Antitumour and Antimalarial Activity of Artemisinin-acridine Hybrids." Bioorganic \& Medicinal Chemistry Letters. Elsevier BV, April 2009. doi:10.1016/j.bmcl.2009.02.028

This Article is brought to you for free and open access by the School of Chemical and Pharmaceutical Sciences at ARROW@TU Dublin. It has been accepted for inclusion in Articles by an authorized administrator of ARROW@TU Dublin. For more information, please contact arrow.admin@tudublin.ie, aisling.coyne@tudublin.ie, gerard.connolly@tudublin.ie.

Funder: Science Foundation Ireland and NDP (for Ireland), BBSRC, DPA, EPSRC and Nuffield Foundation (for UK) and Ministry of Science of Croatia

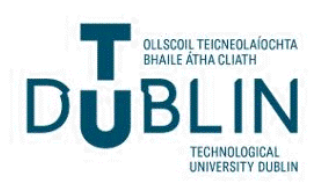




\section{Authors}

Michael Jones, Amy Mercer, Paul Stocks, Louise La Pensee, Rick Cosstick, B. Kevin Park, Miriam Kennedy, Ivo Piantanida, Stephen Ward, Jill Davies, Patrick Bray, Sarah Rawe, Jonathon Baird, Tafadzwa Charidza, Omar Janneh, and Paul O'Neill 


\title{
Antitumour and antimalarial activity of artemisinin-acridine hybrids
}

\author{
Michael Jones ${ }^{\mathrm{a}}$, Amy E. Mercer ${ }^{\mathrm{b}}$, Paul A. Stocks ${ }^{\mathrm{e}}$, Louise J. I. La Pensée ${ }^{\mathrm{a}}$, Rick Cosstick ${ }^{\mathrm{a}}$, B. Kevin Park ${ }^{\mathrm{b}}$,
} Miriam E. Kennedy ${ }^{c, d}$, Ivo Piantanida ${ }^{d}$, Stephen A. Ward ${ }^{\mathrm{e}}$, Jill Davies ${ }^{\mathrm{e}}$, Patrick G. Bray ${ }^{\mathrm{e}}$, Sarah L. Rawe ${ }^{\mathrm{c}, *}$, Jonathan Baird $^{\mathrm{f}}$, Tafadzwa Charidza ${ }^{\mathrm{f}}$, Omar Janneh ${ }^{\mathrm{b}, \mathrm{f}}$, Paul A. Stocks ${ }^{\mathrm{a}}$, Paul M. O’Neill ${ }^{\mathrm{a}, *}$

Q2 a Department of Chemistry, University of Liverpool, Crown Street, Liverpool L69 7ZD, UK

${ }^{\mathrm{b}}$ Department of Pharmacology, University of Liverpool, UK

${ }^{\mathrm{c}}$ Focas Institute, Dublin Institute of Technology, Camden Row, Dublin, D8, Ireland

${ }^{\mathrm{d}}$ Division of Organic Chemistry and Biochemistry, Rudjer Boskovic Institute, Zagreb, Croatia

$10 \quad$ e Liverpool School of Tropical Medicine, Pembroke Place, Liverpool L3 5QA, UK

${ }_{\mathrm{f}}^{\mathrm{f}}$ University of Ulster, Cromore Road, Coleraine, Co., Londonderry, BT52 1 SA Northern Ireland, Ireland

\section{A R T I C L E I N F O}

\section{Article history:}

Received 14 November 2008

Revised 5 February 2009

Available online $\mathrm{xxxx}$

Keywords:

Artemisinin

Acridine

Antimalarial

Anticancer

Apoptosis

DNA

Confocal microscopy

\section{A B S T R A C T}

Artemisinin-acridine hybrids were prepared and evaluated for their in vitro activity against tumour cell lines and a chloroquine sensitive strain of Plasmodium falciparum. They showed a 2-4-fold increase in activity against HL60, MDA-MB-231 and MCF-7 cells in comparison with dihydroartemisinin (DHA) and moderate antimalarial activity. Strong evidence that the compounds induce apoptosis in HL60 cells was obtained by flow cytometry, which indicated accumulation of cells in the G1 phase of the cell cycle.

(c) 2009 Published by Elsevier Ltd.
Artemisinin $\mathbf{1}$ and its semisynthetic and synthetic analogues are effective antimalarial agents and are used to treat chloroquine resistant strains of the disease. Since the early 1990s they have also been shown to have antiproliferative and antitumour activity. ${ }^{1-5}$ Their activity is greatest against rapidly proliferating neoplastic cells with high iron content, since their mode of action almost certainly involves iron(II) catalysed reductive cleavage of the peroxide bond leading to the formation of C-centred radical or cationic intermediates able to alkylate biomolecules and induce cell death. ${ }^{6-10}$ We and others have postulated that a possible cellular target of these alkylating intermediates is $\mathrm{DNA}^{10,11}$ and hoped to enhance their antitumour properties by preparing DNA-targeted 1,2,4-trioxane-acridine hybrids. Acridines are known to intercalate with DNA and have been employed as antibacterial, antiparasitic and antitumour agents, ${ }^{12,13}$ moreover their fluorescent properties allow the use of confocal microscopy to examine the accumulation and cellular location of these drug hybrids. ${ }^{14}$

Hybrid drugs are formed by covalently linking two distinct chemical moieties with differing biological modes of action with the aim of creating bitherapies that have improved biological activ-

\footnotetext{
* Corresponding author.

E-mail address: p.m.oneill01@liv.ac.uk (P.M. O’Neill).
}

ity and are less susceptible to the development of drug resistance. ${ }^{15-17}$ We have synthesised a short series of artemisininacridine hybrids in which a 1,2,4-trioxane derived from artemisinin has been covalently linked to the 9-diaminoalkyl-6-chloro-2methoxyacridines 2-5, and evaluated these hybrids for their in vitro antitumour and antimalarial activity (Fig. 1).

The hybrids were designed to incorporate a metabolically stable C-10 carba linkage at the 1,2,4-trioxane moiety, therefore the carboxylic acid 6 was prepared from C-10 allyldeoxoartemisinin. ${ }^{18}$ Ozonolysis of the terminal double bond in methanol and reduction of the intermediate ozonide with triphenylphosphine afforded the aldehyde in $76 \%$ yield, followed by oxidation with sodium chlorite to give the carboxylic acid in quantitative yield. Treatment of the
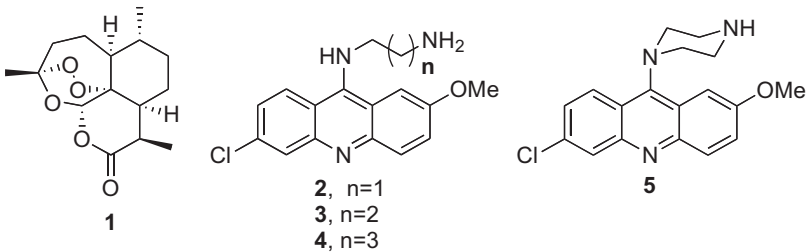

$3, n=2$

Figure 1. 
acid with oxalyl chloride followed by addition of the appropriate 9(diaminoalkyl)acridine afforded the hybrids $\mathbf{Z - 1 0}$ in moderate to good yields (55-74\%), Scheme $1 .^{19}$ The 9-(diaminoalkyl)acridines 2-5 were prepared from 6,9-dichloro-3-methoxyacridine and the corresponding diamines in the presence of phenol.

The hybrids were evaluated for their in vitro activity against four tumour cell lines (HL60, Colon HT29-AK and Breast MDAMB-231 and MCF-7 $)^{20}$ and against a chloroquine sensitive strain of P.falciparum (3D7) ${ }^{21}$ relative to DHA as the control (Tables 1 and 2).

The hybrids were cytotoxic in the cell lines evaluated, with the exception of 10, towards HT29-AK (Table 1). The rank order of sensitivity of the cells to the hybrids were as follows: HL60 > MCF$7>$ MDA-MB-231 > HT29-AK. The observed cytotoxicity of the hybrids and DHA against HL60 cells was anticipated since this cell line is characterised by its rapid proliferation and high iron content. In HL60, MDA-MB-231 and MCF-7 cells, the hybrids displayed activity 2-4-fold greater than DHA. In HT29-AK cells, only hybrid 8 was more active than DHA; the remaining hybrids displayed only moderate activity with the acridine apparently inhibiting the activity of the 1,2,4-trioxane. In HL60 cell lines the side-chain acridine 2 was also examined and shown to have activity of $12.5 \mu \mathrm{M}$. This indicates that the addition of the endoperoxide to this unit enhances cytotoxicity; in breast cancer cell lines HT29-AK and MDA-MB-231 this is clearly not the case since the hybrids are less potent than 2. The hybrids were also evaluated for their in vitro antimalarial activity against chloroquine sensitive 3D7 strain of P. falciparum but none of them were more active than the positive controls (DHA and artemether). Indeed, only $\mathbf{7}$ had good activity, $100 \quad$ while $\mathbf{8}$ and $\mathbf{9}$ displayed moderate activity and $\mathbf{1 0}$ was more than a 100 times less active than DHA (Table 2).

The ability of hybrid $\mathbf{8}$ to induce apoptosis was assessed in HL60 cells by flow cytometric measurement of mitochondrial membrane depolarisation, ${ }^{22}$ DNA degradation ${ }^{23}$ and Western blot analysis of caspase- 3 activation. ${ }^{24}$ This compound was shown to induce mitochondrial membrane depolarisation in a concentration-dependent manner, reaching a significant level at $\hat{1} \mu \mathrm{M}$ increasing until a
Table 1

Cytotoxicity results for compounds 7-10 and DHA against HL60, HT29-AK, MDA-MB231 and MCF-7 tumour cell lines

\begin{tabular}{lllll}
\hline Compds & HL60 & HT29-AK & MDA-MB-231 & MCF-7 \\
\hline Cytotoxicity & $I C_{50}, \mu M^{\mathrm{a}}$ & & & \\
$\mathbf{2}$ & $12.5( \pm 0.25)$ & $6.57( \pm 1.34)$ & $8.12( \pm 1.13)$ & ND \\
$\mathbf{7}$ & $1.17( \pm 0.35)$ & $193.55( \pm 22.88)$ & $48.98( \pm 7.72)$ & $13.69( \pm 1.78)$ \\
$\mathbf{8}$ & $3.08( \pm 0.13)$ & $9.91( \pm 1.85)$ & $11.64( \pm 0.23)$ & $11.85( \pm 0.19)$ \\
$\mathbf{9}$ & $1.58( \pm 0.72)$ & $247.27( \pm 44.13)$ & $43.30( \pm 1.39)$ & $11.70( \pm 0.22)$ \\
$\mathbf{1 0}$ & $0.56( \pm 0.17)$ & $>750$ & $21.14( \pm 0.86)$ & $3.51( \pm 0.42)$ \\
DHA & $2.41( \pm 0.71)$ & $16.12( \pm 1.10)$ & $99.76( \pm 10.96)$ & $45.23( \pm 3.54)$ \\
\hline
\end{tabular}

${ }^{\text {a }}$ Values are means of three experiments; standard deviation is given in parentheses. ND-not determined.

Table 2

Results for antimalarial activity of compounds 7-10 against chloroquine sensitive 3D7 P. falciparum

\begin{tabular}{ll}
\hline Compds & $\mathrm{IC}_{50}, \mathrm{nM}^{\mathrm{a}}$ \\
\hline $\mathbf{7}$ & $5.96( \pm 1.50)$ \\
$\mathbf{8}$ & $22.42( \pm 1.97)$ \\
$\mathbf{9}$ & $20.34( \pm 3.11)$ \\
$\mathbf{1 0}$ & $289.52( \pm 10.52)$ \\
Artemether & $3.53( \pm 1.91)$ \\
DHA & $2.30( \pm 1.50)$ \\
\hline
\end{tabular}

a Values are means of three experiments; standard deviation is given in parentheses.

maximum effect, $98 \pm 3 \%$ of cells depolarised, was observed at $10 \mu \mathrm{M}$ after $24 \mathrm{~h}$. Analysis of cellular DNA content with PI staining showed concentration-dependent formation of a sub- $G_{0} / G_{1}$ population with a maximum effect of $57 \pm 2 \%$ of cells at $10 \mu \mathrm{M}$ after $24 \mathrm{~h}$ (Fig. 2A). Western blot analysis of caspase-3 activity also showed concentration-dependent appearance of the catalytically active subunit of processed caspase- 3 with a concomitant decrease of the inactive $32 \mathrm{kDa}$ precursor (Fig. 2B). Together these results are strongly indicative of the ability of hybrid $\mathbf{8}$ to induce cell death by apoptosis.

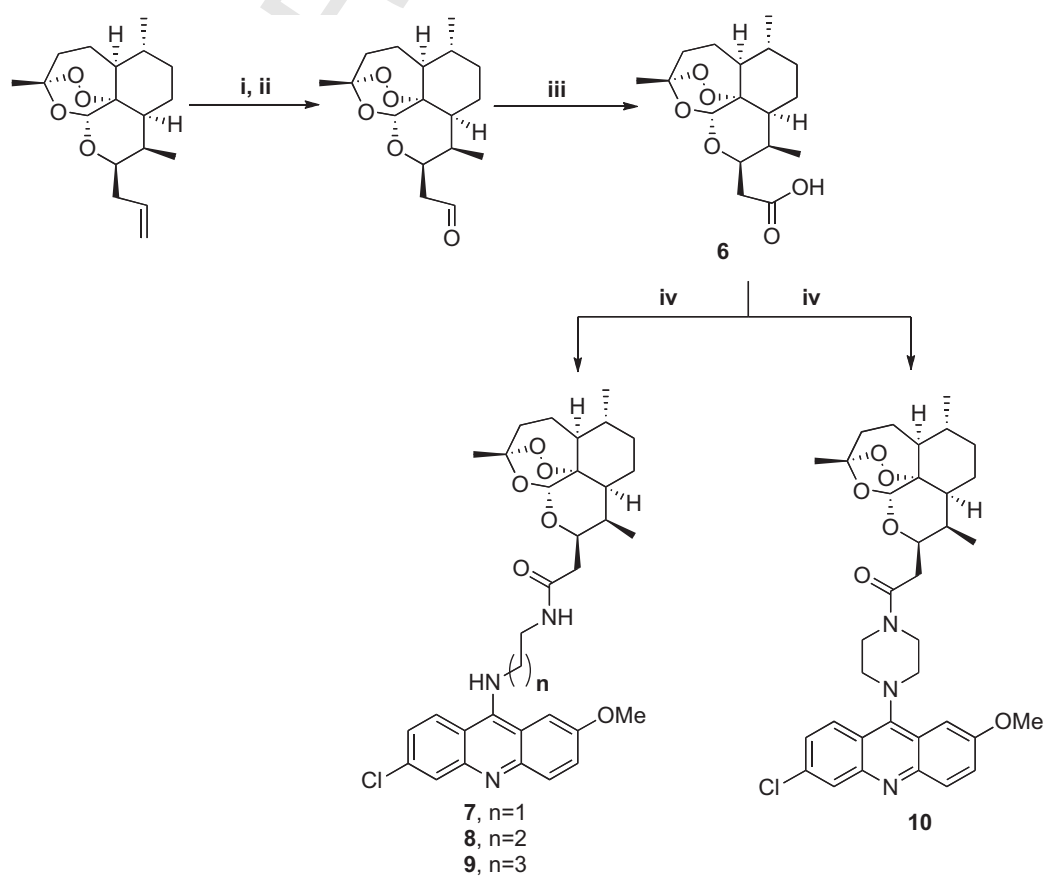

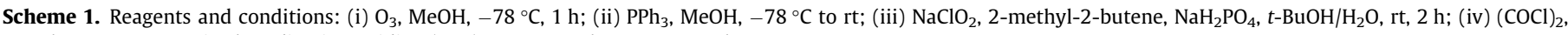
$\mathrm{CH}_{2} \mathrm{Cl}_{2}, 0^{\circ} \mathrm{C} \rightarrow \mathrm{rt}, 90 \mathrm{~min}$ then diaminoacridine $(\mathbf{2 - 5}), \mathrm{NEt}_{3}, \mathrm{CH}_{2} \mathrm{Cl}_{2}, 0^{\circ} \mathrm{C} \rightarrow \mathrm{rt}, 16 \mathrm{~h}$. 
A
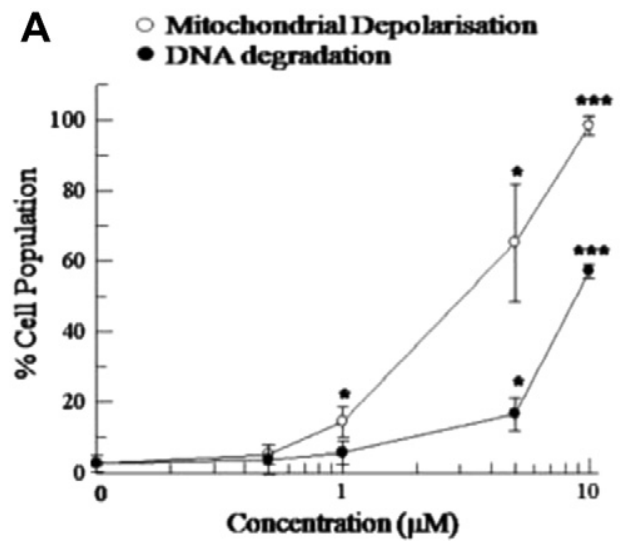

B

$\begin{array}{lllll}1 & 2 & 3 & 4 & 5\end{array}$

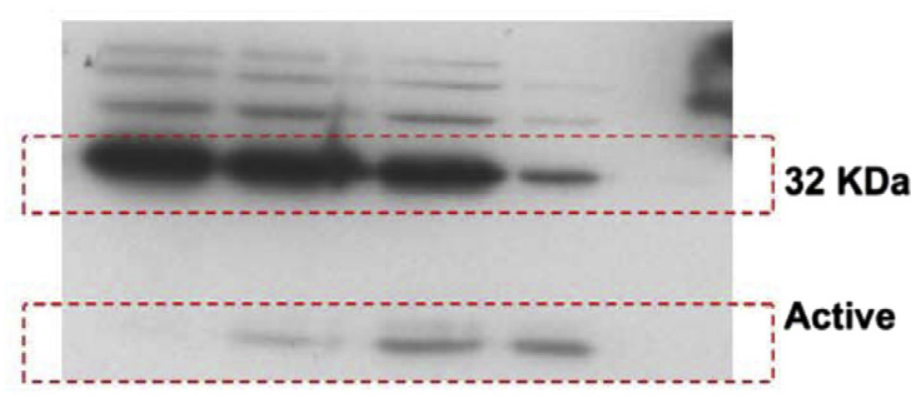

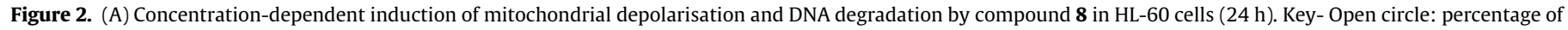

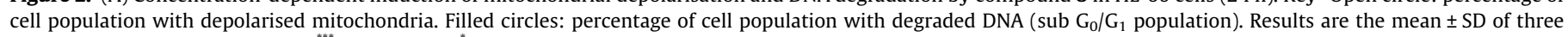

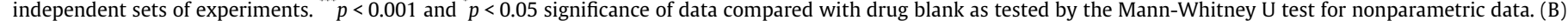

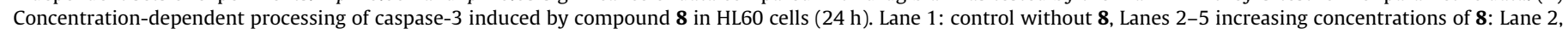
$0.5 \mu \mathrm{M}$, Lane 3: $1.0 \mu \mathrm{M}$, Lane 4: $5 \mu \mathrm{M}$ and Lane 5: $10 \mu \mathrm{M}$.

Confocal microscopy was used to determine the cellular location of both hybrid 7 and 9-(1,2-diaminoethyl)-6-chloro-2-methoxyacridine 2 in treated parasite infected erythrocytes and MRC50 human lung fibroblast cells ( 7 was selected based on the fact that this hybrid was the most potent antimalarial in the series). Both hybrid $\mathbf{7}$ and 9-aminoacridine $\mathbf{2}$ were shown to accumulate selectively in infected erthyrocytes and on the nuclear membrane of MRC- 5 cells (Fig. 3A-C). In malaria parasites acridine $\mathbf{2}$ was easily removed by washing with a buffer solution (Fig. 3B) whereas the endoperoxide hybrid 7 remained, implying covalent binding of the hybrid (and not the acridine) to intraparasitic cellular biomol- ecules (Fig. 3 C). Similar experiments were performed in the presence of a ferric iron chelator (desferrioxamine (DFO), and under these conditions the hybrid was removed from the cells on washing with the buffer (data not shown). ${ }^{14}$ This result implies that chelatable iron catalysed reductive cleavage of the peroxide bond is required for covalent binding of the hybrid to the cellular targets. (Since DFO is selective for ferric iron it is apparent that intraparasitic reduction of iron to its ferrous form must be achieved to facilitate endoperoxide bond cleavage.)

Finally, the in vitro affinity of hybrid $\mathbf{7}$ and acridine $\mathbf{2}$ for calf thymus (ct)-DNA and poly A-poly U was investigated spectrophoto-
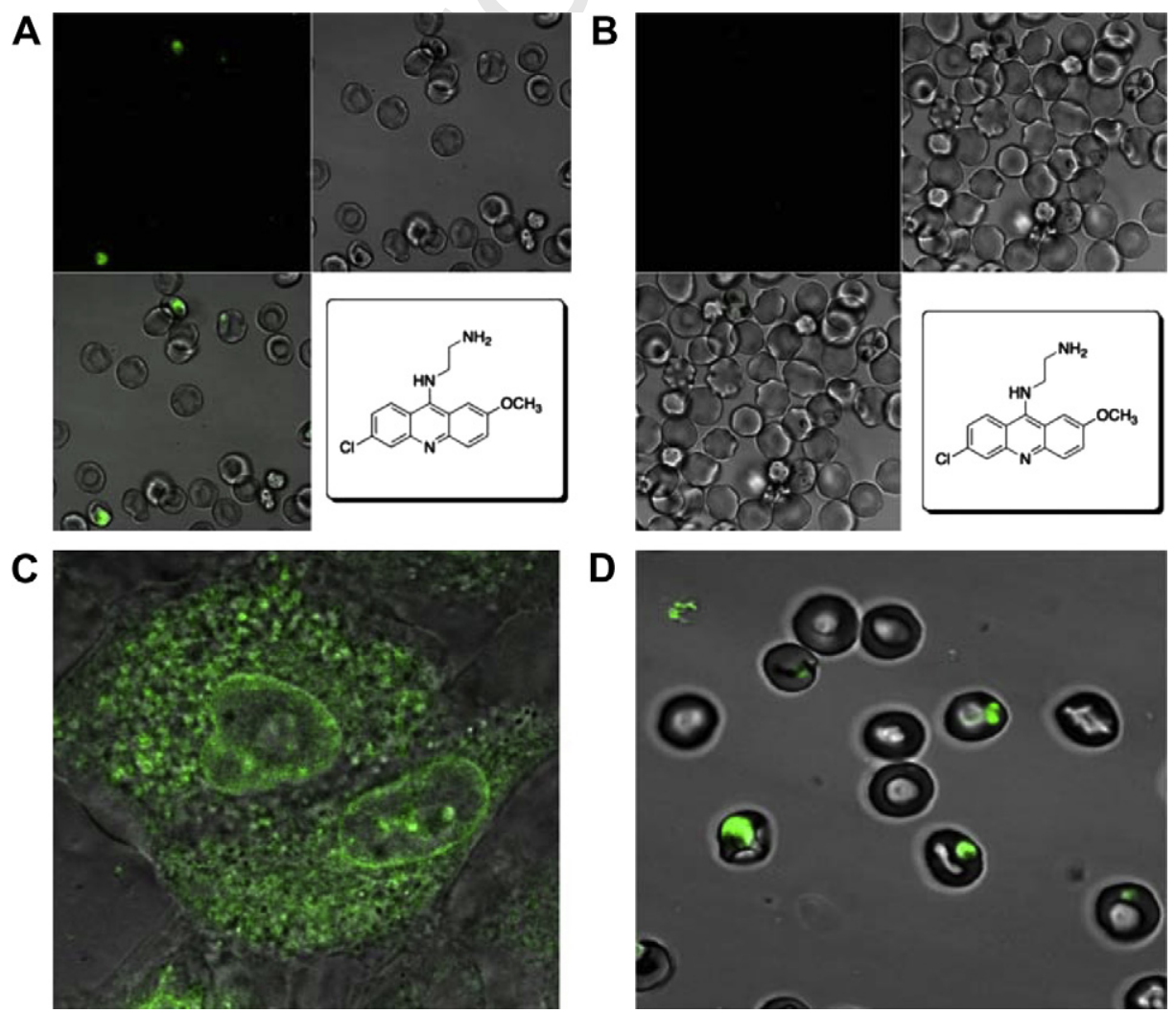

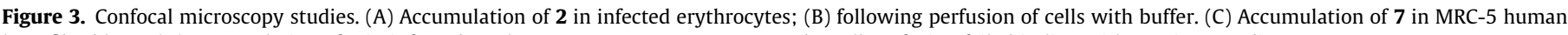
lung fibroblasts. (D) Accumulation of $\mathbf{7}$ in infected erythrocytes. Attempts to remove $\mathbf{7}$ by cell perfusion failed in line with previous studies. 


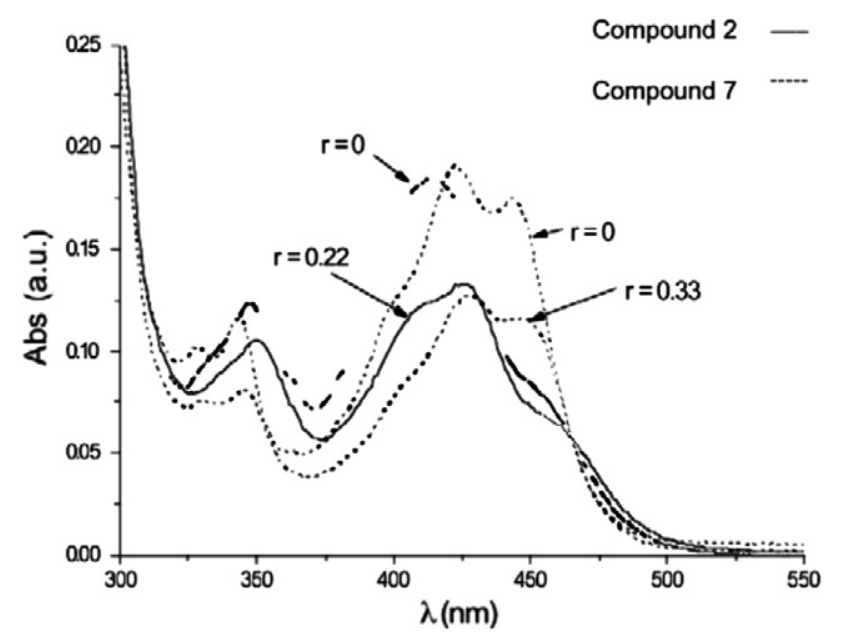

Figure 4. UV/vis spectra of $\mathbf{2}$ and $7\left(c=5 \times 10^{-5} \mathrm{~mol} \mathrm{dm}^{-3}\right)$ and complexes $\mathbf{2} /$ ctDNA and $7 /$ ctDNA at different ratios $r=[2$ or 7$] /[$ ctDNA], pH 7, Na cacodylate buffer, $I=0.05 \mathrm{M}$

metrically using thermal melting analysis, electronic absorption, fluorimetric binding titrations and circular dichroism (CD) analysis. Addition of ct-DNA at concentrations close to equimolar in respect of studied compounds yielded significant batochromic shifts in the electronic absorption spectra of 7 and $\mathbf{2}$ (Fig. 4) at wavelengths characteristic for acridine moiety. ${ }^{25}$ However, at higher excess of ct-DNA over 2, 7 precipitation occurred, hampering collection of enough data points for accurate processing by Scatchard equation. ${ }^{26}$

Table 3

$\Delta T_{\mathrm{m}}$ values ${ }^{\mathrm{a}}\left({ }^{\circ} \mathrm{C}\right)$ of studied ds-polynucleotides upon addition of $\mathbf{2}$ and $\mathbf{7}$ at ratio $r^{\mathrm{b}}=0.3$ at $\mathrm{pH} 7, \mathrm{Na}$ cacodylate buffer, $0.02 \mathrm{M}(I=0.005 \mathrm{M})^{\mathrm{a}}$

\begin{tabular}{lll}
\hline Polynucleotide & $\Delta T_{\mathrm{m}} \mathrm{w} / \mathbf{2}\left({ }^{\circ} \mathrm{C}\right)$ & $\Delta T_{\mathrm{m}} \mathrm{w} / \mathbf{7}\left({ }^{\circ} \mathrm{C}\right)$ \\
\hline ctDNA & 9.3 & 3.1 \\
Poly A-poly U & 2.2 & 2.4 \\
Poly A-poly T & 2.9 & 0.6 \\
\hline
\end{tabular}

a Error in $\Delta T_{\mathrm{m}}: \pm 0.5^{\circ} \mathrm{C}$.

b $r=$ [compound]/[polynucleotide].

c With the exception of this experiment (where $I=0.05 \mathrm{M}$ ) melting studies were performed at $I=0.005 \mathrm{M}$ due to the very weak effects at $I=0.05 \mathrm{M}$.

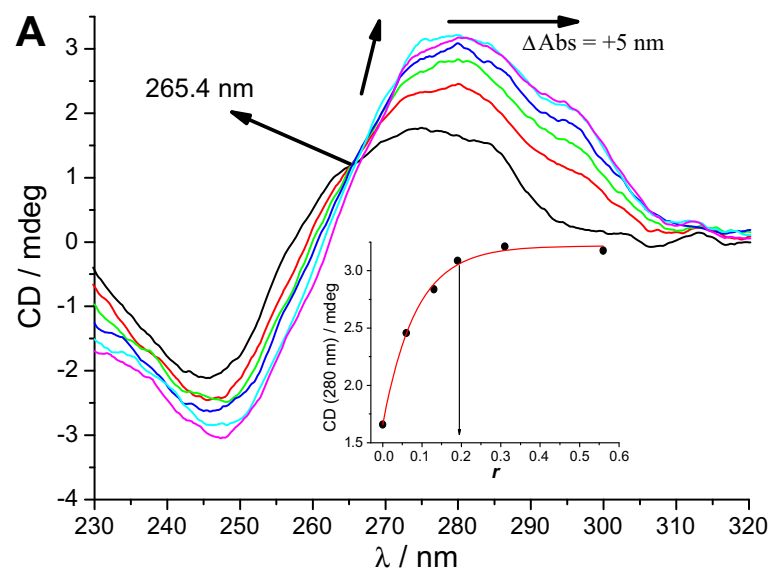

At variance to UV/vis titrations, strong fluorescence of $\mathbf{2}$ and $\mathbf{7}$ allowed fluorimetric titrations with polynucleotides at significantly lower concentrations, at which no precipitation was observed. Emission of both $\mathbf{2}$ and $\mathbf{7}$ was strongly quenched by addition of ct-DNA and poly A-poly $U$ and processing of the fluorimetric titration data by Scatchard equation ${ }^{26}$ gave similar binding constants (in the range $K_{s} \approx 10^{6} \mathrm{M}^{-1}$ ) and ratio binding $n_{\text {[compound]/[polynucleotide] }}$ of about 0.2 . However, in thermal melting studies addition of $\mathbf{2}$ generally yielded a significantly stronger stabilisation effect on double stranded polynucleotides than its hybrid analogue 7 (Table 3).

However, CD studies were the most elucidating. CD analysis of ct-DNA (Fig. 5) and poly A-poly $U$ in the presence of $\mathbf{2}$ showed an increase in the CD of DNA/RNA (220-300 nm range) and a weak negative induced $C D$ at about $430 \mathrm{~nm}$ (absorption attributed to the acridine), characteristic of intercalation. ${ }^{27}$ However, there was no change in the CD spectra of either ct-DNA or poly A-poly $\mathrm{U}$ upon addition of hybrid 7, indicating that the acridine moiety of the hybrid is not intercalated into the double helix. That would imply that linking the acridine moiety to the trioxane prevents intercalation in double stranded polynucleotide or at least diminishes its role in binding, presumably due to the intramolecular aromatic stacking interaction between acridine and trioxane moiety (visible from comparison of the UV/vis spectrum of 2 and 7). Consequently, changes in the electronic emission and absorption spectra of $\mathbf{7}$ upon addition of studied polynucleotides and the increase in melting temperature are caused either by counterion stabilisation or by mixed binding modes including to some electrostatic, hydrophobic and van der Waals interactions as well as intercalation of the acridine as a minor contribution. ${ }^{28}$

In summary, artemisinin-acridine hybrids display promising antitumour activity in HL60, MDA-MB-231 and MCF-7 cells. They have been shown to induce cell death by apoptosis and to covalently bind to their intraparasitic cellular targets in the presence of iron(II). Linking an acridine to an artemisinin derivative was shown to enhance antitumour activity in the HL60 leukaemia cell line (comparing 2 and 7), while it had a largely inhibitory effect in HT29-AK and MDA-MB-231 cells. Compared to DHA the hybrids had decreased in vitro antimalarial activity. Although hybrid 7 was shown to have high affinity toward DNA/RNA, intercalation of hybrid 7 into DNA/RNA in vitro was not dominant binding mode, presumably due to the competitive intramolecular aromatic stacking interaction between acridine and trioxane moiety. Future work will involve the synthesis and evaluation of redesigned hybrids in which longer linkers between the two moieties and a variety

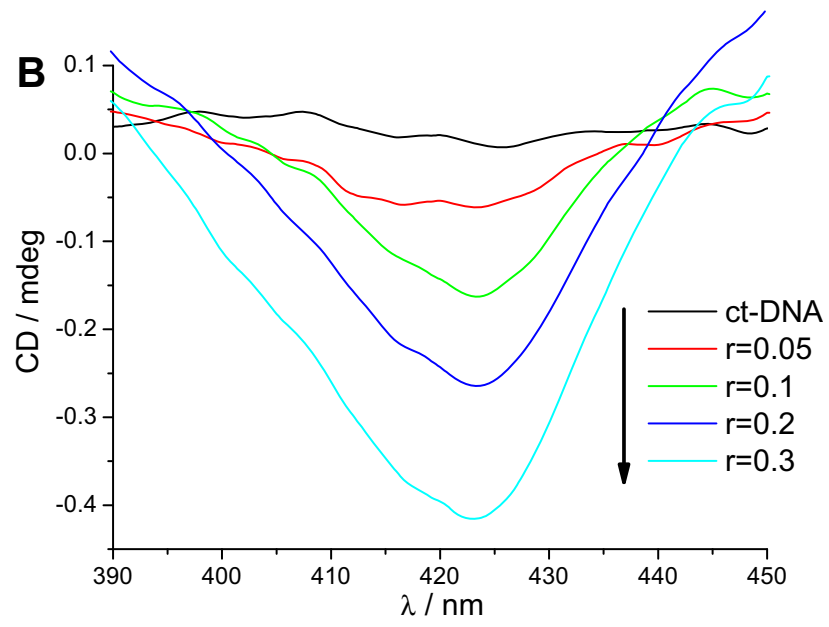

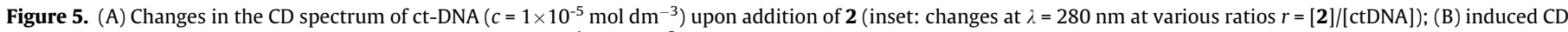
band of acridine moiety at various ratios $r\left(c(\mathrm{ct}-\mathrm{DNA})=1 \times 10^{-4} \mathrm{~mol} \mathrm{dm}^{-3}\right)$. Carried out at $\mathrm{pH} 7$, Na cacodylate buffer, $I=0.05 \mathrm{M}$. 
of DNA targeting groups will be used in the hope of achieving greater DNA affinity and enhanced antitumour activity.

\section{Acknowledgments}

MJ would like to thank the BBSRC for a studentship (BBS/S/P/ 2003/10353) and L.L. would like to thank the EPSRC for a DTA award. T.C. was a recipient of undergraduate bursary from the Nuffield Foundation. S.R. would like to thank Science Foundation Ireland and the National Development Plan for funding. L.P. is 200 grateful to Ministry of Science of Croatia (Project 098-09829142918) for financial support.

\section{References and notes}

1. Woerdenbag, H. J.; Moskal, T. A.; Pras, N.; Malingre, T. M.; Elferaly, F. S.; Kampinga, H. H.; Konings, A. W. T. J. Nat. Prod. 1993, 56, 849.

2. Jung, M. Bioorg. Med. Chem. Lett. 1997, 7, 1091.

3. Posner, G. H.; Ploypradith, P.; Hapangama, W.; Wang, D. S.; Cumming, J. N.; Dolan, P.; Kensler, T. W.; Klinedinst, D.; Shapiro, T. A.; Zheng, Q. Y.; Murray, C. K.; Pilkington, L. G.; Jayasinghe, L. R.; Bray, J. F.; Daughenbaugh, R. Bioorg. Med. Chem. 1997, 5, 1257.

4. Moore, J. C.; Lai, H.; Li, J. R.; Ren, R. L.; McDougall, J. A.; Singh, N. P.; Chou, C. K. Cancer Lett. 1995, 98, 83.

5. Efferth, T.; Dunstan, H.; Sauerbrey, A.; Miyachi, H.; Chitambar, C. R. Int. J. Oncol. 2001, 18, 767 .

6. Efferth, T.; Benakis, A.; Romero, M. R.; Tomicic, M.; Rauh, R.; Steinbach, D. Hafer, R.; Stamminger, T.; Oesch, F.; Kaina, B.; Marschall, M. Free Radical Biol. Med. 2004, 37, 998.

7. Efferth, T.; Oesch, F. Biochem. Pharmacol. 2004, 68, 3.

8. O'Neill, P. M.; Posner, G. H. J. Med. Chem. 2004, 47, 2945.

9. Efferth, T. Drug Res. Updates 2005, 8, 85.

10. Li, P. C. H.; Lam, E.; Roos, W. P.; Zdzienicka, M. Z.; Kaina, B.; Efferth, T. Cancer Res. 2008, 68, 4347.

11. Jeyadevan, J. P.; Bray, P. G.; Chadwick, J.; Mercer, A. E.; Byrne, A.; Ward, S. A.; Park, B. K.; Williams, D. P.; Cosstick, R.; Davies, J.; Higson, A. P.; Irving, E.; Posner, G. H.; O’Neill, P. M. J. Med. Chem. 2004, 47, 1290.

12. Albert, A.; Goldacre, R. Nature 1948, 161, 95.

13. Denny, W. A. Curr. Med. Chem. 2002, 9, 1655.

14. (a) Eckstein-Ludwig, U.; Webb, R. J.; van Goethem, I. D. A.; East, J. M.; Lee, A. G.; Kimura, M.; O'Neill, P. M.; Bray, P. G.; Ward, S. A.; Krishna, S. Nature 2003, 424 957; (b) Stocks, P. A.; Bray, P. G.; Barton, V. E.; Al-Helal, M.; Jones, M.; Araujo, N. C.; Gibbons, P.; Ward, S. A.; Hughes, R. H.; Biagini, G. A.; Davies, J.; Amewu, R. Mercer, A. E.; Ellis, G.; O'Neill, P. M. Angew. Chem., Int. Ed. 2007, 46, 6278.

15. Takahashi, T.; Tanaka, H.; Matsuda, A.; Doi, T.; Yamada, H.; Matsumoto, T. Sasaki, D.; Sugiura, Y. Bioorg. Med. Chem. Lett. 1998, 8, 3303.

16. Perez, J. M.; Lopez-Solera, I.; Montero, E. I.; Brana, M. F.; Alonso, C.; Robinson, S. P.; Navarro-Ranninger, C. J. Med. Chem. 1999, 42, 5482.

17. Meunier, B. Acc. Chem. Res. 2008, 41, 69.

18. O’Neill, P. M.; Miller, A.; Bishop, L. P. D.; Hindley, S.; Maggs, J. L.; Ward, S. A. Roberts, S. M.; Scheinmann, F.; Stachulski, A. V.; Posner, G. H.; Park, B. K. J. Med. Chem. 2001, 44, 58.

19. Synthesis of hybrid 7: To a stirred solution of artemisinin acid chloride (1 equiv) and appropriate alkylaminoacridine (1 equiv) in anhydrous $\mathrm{CH}_{2} \mathrm{Cl}_{2}$ at $0{ }^{\circ} \mathrm{C}$ was added anhydrous triethylamine (1.1 equiv). The reaction mixture was stirred at low temperature $\left(0^{\circ} \mathrm{C}\right)$ for $18 \mathrm{~h}$ and then allowed to warm to ambient temperature. The volatiles were removed in vacuo and the resultant yellow oil was purified by flash column chromatography on silica gel to give a yellow solid $\left(20: 80=\mathrm{MeOH} / \mathrm{CH}_{2} \mathrm{Cl}_{2}\right)$. Analysis for 7: $\mathrm{mp} 125{ }^{\circ} \mathrm{C}{ }^{1} \mathrm{H}$ NMR: $\left(\mathrm{CDCl}_{3}\right.$
$400 \mathrm{MHz}) \delta 8.40 \mathrm{ppm}(1 \mathrm{H}, \mathrm{br} \mathrm{s}), 8.15(1 \mathrm{H}, \mathrm{d}, J=9.2 \mathrm{~Hz}), 8.10(1 \mathrm{H}, \mathrm{d}, J=2.5 \mathrm{~Hz})$, $7.97(1 \mathrm{H}, \mathrm{d}, J=9.1 \mathrm{~Hz}), 7.40(1 \mathrm{H}, \mathrm{dd}, J=2.4 \mathrm{~Hz}, 9.3 \mathrm{~Hz}), 7.38(1 \mathrm{H}, \mathrm{d}, J=2.1 \mathrm{~Hz})$ $7.20(1 \mathrm{H}, \mathrm{dd}, J=2.1 \mathrm{~Hz}, 9.3 \mathrm{~Hz}), 5.02(1 \mathrm{H}, \mathrm{s}), 4.0(1 \mathrm{H}, \mathrm{s}), 3.91(1 \mathrm{H}, \mathrm{m}), 3.70(3 \mathrm{H}$, $\mathrm{s}), 3.43,(2 \mathrm{H}, \mathrm{m}), 3.28(2 \mathrm{H}, \mathrm{m}), 2.48(1 \mathrm{H}, \mathrm{m}) 2.45-2.17(3 \mathrm{H}, \mathrm{m}) 2.07-1.20(10 \mathrm{H}$, $\mathrm{m})$ including $1.41(3 \mathrm{H}, \mathrm{s}) 0.96(3 \mathrm{H}, \mathrm{d}, J=5.9 \mathrm{~Hz})$ and $0.89(3 \mathrm{H}, \mathrm{d}, J=7.67 \mathrm{~Hz})$; ${ }^{13} \mathrm{C}$ NMR: $\left(\mathrm{CDCl}_{3}, 400 \mathrm{MHz}\right) \delta 174.7,156.8,148.6,148.0,134.9,131.0,128.9$, 128.0, 127.3, 121.9, 118.6, 104.6, 98.0, 96.2, 92.8, 84.5, 67.5, 56.2, 54.0, 44.6, $37.3,36.3,30.8,30.4,29.5,25.3,23.7,22.8,19.0,18.4,11.8,11.4$; HRMS (CI): $\mathrm{C}_{33} \mathrm{H}_{40} \mathrm{ClN}_{3} \mathrm{O}_{6}[\mathrm{M}+\mathrm{H}]^{+}$requires 611.1479 found: 611.1499; Anal. Calcd for $\mathrm{C}_{33} \mathrm{H}_{40} \mathrm{ClN}_{3} \mathrm{O}_{6}$ : C, 64.96; H, 6.61; N, 6.89. Found: C, 65.00; H, 6.78; N, 6.93.

20. Measurement of cytotoxicity using the 3-(4,5-dimethylthiazol-2-yl)-2,5diphenyltetrazolium bromide (MTT) assay: HL-60 Cells $\left(2.5 \times 10^{4} /\right.$ well) were plated in triplicate, in flat bottom 96 -well plates and were exposed to 0.01$100 \mu \mathrm{M}$ of each compound for $72 \mathrm{~h}\left(5 \% \mathrm{CO}_{2}\right.$ at $\left.37^{\circ} \mathrm{C}\right)$. Following incubation, cell viability measurements using the MTT assay were carried out by the addition of $20 \mu \mathrm{L}$ of MTT solution ( $5 \mathrm{mg} / \mathrm{mL}$ in HBSS) to each well and incubating for $3 \mathrm{~h}$ at $37^{\circ} \mathrm{C}$. Thereafter, $100 \mu \mathrm{L}$ of a lysing solution $(20 \% \mathrm{w} / \mathrm{v}$ sodium dodecylsulfate, $50 \% \mathrm{w} / \mathrm{v} N, N$-dimethyl formamide) was added to each well to dissolve the formazan crystals and incubated for an additional $4 \mathrm{hrs}$. The absorbances of the samples were measured at a test wavelength of $570 \mathrm{~nm}$ and a reference wavelength of $590 \mathrm{~nm}$ with a plate reader (MRX, Dynatech Laboratories). All results were expressed as a percentage of vehicle only cells. The $\mathrm{IC}_{50}$ values were calculated from individual inhibition curves plotted by Grafit software. The same method was used to determine cytotoxicity against HT29-AK and MDA-MB-231 cells at drug concentrations up to $750 \mu \mathrm{M}$.

21. For in vitro antimalarial assessment versus the 3D7 strain of Plasmodium falciparum the following protocol was employed. Parasites were maintained in continuous culture using the method of Jensen and Trager: (a) Trager, W.; Jensen, J. B. Science 1976, 193, 673-675; Antimalarial activity was assessed with an adaption of the $48 \mathrm{hr}$ sensitivity assay of Desjardins et al. using [3H]hypoxanthine incorporation as an assessment of parasite growth: (b) Desjardins, R. E.; Canfield, C. J.; Haynes, J. D.; Chulay, J. D. Antimicrob. Agents Chemother. 1979, 16, 710-718.

22. Mitochondrial membrane potential (MMP) was measured using tetramethylrhodamine ethyl ester (TMRE) to quantify HL-60 cells with a high MMP. Drug treated cells $\left(5 \times 10^{5}\right.$ cells $)$ were washed in HBSS and the resultant cell pellet was resuspended in $500 \mu \mathrm{L}$ of TMRE solution (50 nM in HBSS) and incubated for $10 \mathrm{~min}$ at $37^{\circ} \mathrm{C}$. A minimum of 500 cells were measured by flow cytometry on fluorescence channel FL-2 (Coulter Epics, XL Software). The data was analysed using WinMDI, v2.8 software (Scripps Institute, California, USA).

23. The DNA major groovebinder PI, was used to quantify cellular DNA content to measure the formation of a sub-G0/G1 population of HL-60 cells. Drug treated cells $\left(1 \times 10^{6}\right)$ were washed twice in HBSS, fixed in $1 \mathrm{~mL}$ of ice-cold $70 \%$ ethanol, and frozen at $-20{ }^{\circ} \mathrm{C}$. After $2 \mathrm{~h}$ the $70 \%$ ethanol was removed and the cell pellet was resuspended in $1 \mathrm{~mL}$ of PI stock solution (phosphate-buffered saline containing $40 \mu \mathrm{g} / \mathrm{mL}$ PI, $0.1 \mathrm{mg} / \mathrm{mL}$ RNase, and $3.8 \mathrm{mM}$ sodium citrate)) and incubated at $37{ }^{\circ} \mathrm{C}(30 \mathrm{~min})$. A minimum of 5000 cells were analysed by flow cytometry. PI fluorescence was measured on fluorescence channel FL-2. The proportion of cells in each stage of the cell cycle was calculated from the DNA content of the cell using WinMDI, v2.8 software.

24. Cell lysate samples were prepared, cells $\left(3 \times 10^{6}\right)$ were washedbefore sonication with a sonic probe, $(2 \times 5 \mathrm{~s}$ cycles $)$. The samples were then assayed for protein content using the Bradford assay. Lysates, with equal amounts of protein $(20 \mu \mathrm{g}$ per lane), were mixed with SDS-PAGE loading buffer and denatured at $95^{\circ} \mathrm{C}$ for $3 \mathrm{~min}$ prior to being resolved on $14 \%$ SDSPAGE. Proteins were transferred to nitrocellulose membrane for Western blotting analysis as described previously. ${ }^{29}$ Zimmermann, Physicochemical and Q3 cytochemical investigations on the binding of ethidium and acridine-dyes to DNA and to organelles in living cells.

25. Zimmermann, H. W. Angew. Chem., Int. Ed. Engl. 1986, 25, 115

26. McGhee, J. D.; von Hippel, P. H. J. Mol. Biol. 1974, 103, 679.

27. Eriksson, M.; Norden, B. In Drug-Nuc. Acid Int., 2001; Vol. 340, p-68.

28. Long, E. C.; Barton, J. K. Acc. Chem. Res. 1990, 23, 271. 